\title{
The business rescue practitioners' professionalism: are we there yet?
}

\author{
Onesmus Ayaya \\ Marius Pretorius \\ Department of Business Management \\ University of Pretoria, South Africa
}

Keywords:

business, construction, framework, practitioner, professionalism, rescue

\begin{abstract}
Purpose and context: The purpose of the study was to explore the construction of professionalism in a multiple professional bodies (MPB) landscape in South Africa (SA) and demonstrate how this construction can be used to enhance a professional accreditation regime. Professional accreditation has become a prerequisite for business rescue practitioners (BRPs). The Companies and Intellectual Property Commission (CIPC) licensing is linked to multiple professional bodies' knowledge and practices but are not generic. This study was guided by one key question: How do PBs providing BRPs construct professionalism, and to what extent can the existing construction of professionalism facilitate the development of a professional accreditation regime?

Research design and methods: A qualitative research design used required researchers to use four consecutive steps, namely (a) interviewing member services' managers at four professional bodies (PBs); (b) systematic content analysis of codes of professional conduct and policy statements to identify constituent professionalism notions; (c) a systematic search of the literature to identify notions of professionalism mentioned in definitions and explanations of the construct; and (d) analysis of notions of professionalism using the constant comparison procedure to reveal critical themes.

Results: A total of 90 separate notions of professionalism were identified in the 192 scholarly papers included in our study. The identified themes within business rescue practitioner (BRP) professionalism (emphasising relational aspects) point to practitioner dealings with (i) clients (business rescue candidates); (ii) government and others; (iii) the PB; and (iv) oneself to gain the essence of occupation. There is fragmentation between the constructed conceptualisations of professionalism among PBs, leading to an incoherent and inconsistent expert accreditation regime.

Practical implications and value: The results from the indicated exploration steps were used to advance a programmatic framework to construct professionalism in an MPB landscape and set a future research agenda. The results also show that business rescue practitioners' professionalism cannot be attained in a multi-professional body setting with an integrated professional accreditation framework.
\end{abstract}

Corresponding author: Onesmus Ayaya

Email addresses for the corresponding author: onesimas.ayaya@gmail.com

The first submission received: 13 July 2021

Revised submission received: 10 September 2021

Accepted: 21 October 2021

\section{Introduction}

Business rescue practitioners (BRPs) have faced allegations of abuse (Text Box 1), and, therefore, professional accreditation has become necessary. The Companies and Intellectual Property Commission (CIPC) licensing of BRPs is linked to multiple professional bodies' knowledge and practices. The CIPC s seems to have realised that the institutional erection and embeddedness of practitioners' practices are core to the business rescue acquisition of a professional identity and practice interests. Fatemi, Hasseldine, and Hite (2020) argue that practitioners act with professionalism when they adhere to a code of professional conduct (CPC), and therefore, professionalism is not a principle of ethics. Codes of professional conduct (CPCs) are associated with institutions. The Companies and Intellectual Property Commission (CIPC, 2020) issued continuing professional development (CPD) to enhance professionalism among practitioners from multiple professional bodies (MPBs). The CIPC requires business rescue practitioners to be members 
of accredited professional bodies instead of a professional body. Therefore, it is worth exploring the following questions given the present $\mathrm{BRP}$ licensing regime:

- How do PBs providing BRPs construct professionalism?

- What is the extent to which the existing construction of professionalism facilitates the development of a professional accreditation regime?

- How should business rescue practitioner professionalism be constructed given the BRP accreditation requirements?

The members of the listed PBs (Table 2) did not train in BRP practices, and the construction of professionalism is bound to be different. Pretorius (2014) contend that BRP is an occupation that emanated from the promulgation of the Companies Act (Act No. 71 of 2008). It was hoped that the BRP profession would emerge because of the implementation of the Act.

Understanding the construction of professionalism among the BRP-supplying professional bodies (PBs) is vital in the learning and development of BRPs. The demand for BRP services (Table 1) prompted a rethink of how BR needs can be met by professionals holding membership with PBs recognised by the South African Qualifications Authority (SAQA) and the CIPC. Table 1 shows the number of BRs since 2011. The volume of business rescue work has been growing. Table 2 shows a summary of BRPs registered with different PBs in compliance with the Act's requirements. As of 30 September 2020, four PBs contribute $81 \%$ of the registered BRPs. These PBs are the South African Institute of Chartered Accountants (SAICA) (27\%), the South African Restructuring and Insolvency Practitioners Association (SARIPA) (22\%), the Law Society (20\%) and the Turnaround Management Association of South Africa (BRA-SA) (12\%). Table 2 further shows that $42 \%$ of the BRPs on the CIPC register were not linked to any of the listed PBs. In terms of the regulations, the unclassified BRPs must apply through the recognised PBs. This move supports the use of professionals in BR work, and by extension, professionalism should have a shared constructed meaning.

Table 1: Business rescue case and volume of work

\begin{tabular}{|c|c|c|c|c|c|c|c|c|c|}
\hline & \multicolumn{7}{|c|}{ Years } & & \\
\hline Month & $\begin{array}{l}2011- \\
2012\end{array}$ & $\begin{array}{l}2012- \\
2013\end{array}$ & $\begin{array}{l}2013- \\
2014\end{array}$ & $\begin{array}{l}2014- \\
2015\end{array}$ & $\begin{array}{l}2015- \\
2016\end{array}$ & $\begin{array}{l}2016- \\
2017\end{array}$ & $\begin{array}{l}2017- \\
2018\end{array}$ & Total & Mean \\
\hline April & 0 & 30 & 39 & 24 & 42 & 25 & 16 & 176 & 25 \\
\hline May & 5 & 45 & 50 & 39 & 33 & 40 & 27 & 239 & 34 \\
\hline June & 28 & 26 & 37 & 34 & 21 & 36 & 43 & 225 & 32 \\
\hline July & 25 & 23 & 47 & 43 & 67 & 40 & 23 & 268 & 38 \\
\hline August & 38 & 59 & 49 & 66 & 56 & 45 & 33 & 346 & 50 \\
\hline September & 81 & 55 & 26 & 42 & 34 & 29 & 41 & 308 & 44 \\
\hline October & 27 & 47 & 45 & 44 & 57 & 34 & 33 & 287 & 41 \\
\hline November & 42 & 56 & 28 & 34 & 55 & 32 & 47 & 294 & 42 \\
\hline December & 59 & 18 & 14 & 25 & 21 & 22 & 18 & 177 & 25 \\
\hline January & 67 & 14 & 35 & 31 & 22 & 23 & 25 & 217 & 31 \\
\hline February & 43 & 44 & 31 & 24 & 47 & 28 & 32 & 249 & 35 \\
\hline March & 28 & 50 & 32 & 49 & 38 & 31 & 30 & 258 & 37 \\
\hline Total & 443 & 467 & 433 & 455 & 493 & 385 & 368 & 3044 & 435 \\
\hline Invalid filings & (61) & (27) & (24) & (42) & (12) & (6) & (5) & (177) & (25) \\
\hline BR ended & 320 & 298 & $\underline{269}$ & 250 & $\underline{288}$ & $\underline{184}$ & $\underline{82}$ & $\underline{1691}$ & 242 \\
\hline $\begin{array}{ll}\text { Active as } & \text { of } \\
31 \text { March } 2018 & \end{array}$ & $\underline{\underline{62}}$ & $\underline{\underline{142}}$ & $\underline{\underline{140}}$ & $\underline{\underline{163}}$ & $\underline{\underline{193}}$ & $\underline{\underline{195}}$ & $\underline{\underline{281}}$ & $\underline{\underline{1176}}$ & \\
\hline
\end{tabular}

Source: Researchers' synthesis of the CIPC data on business rescue firms.

The constitution of the business rescue practitioner (BRP) occupation in South Africa (SA) occurred with the promulgation of the Companies Act (Act No. 71 of 2008, from now on the "Act"). The legal provisions in the Act took effect on 1 May 2011 and allow practitioners from MPBs (Table 2) to provide business rescue practitioners' services. The following questions are worth asking: How is professionalism 
constructed in the MPB landscape of business rescue? What dimensions of professionalism apply to the $\mathrm{BRP}$ or the BRP occupation in SA? These questions must be answered for the BRP occupation to improve and reach the intended practice goals.

Therefore, the article's purpose is to explore the constructed meaning of professionalism as an organising framework for the MPBs shouldering BRP work and provide a pragmatic path for the construction and documentation of professionalism. The rest of the paper covers the conceptual framework of professionalism, the problem statement, research design, results and discussion, the emerging conceptual framework for constructing professionalism and conclusions.

\section{The conceptual context of professionalism}

Professionalism as an organising framework for the business rescue work is not coherently defined given the multiple professional body context. Professionalism is a meaningful learning and development outcome in professional certification (Macheridis \& Paulsson, 2019). Evans (2011) argues that professional standards lead to a notion of professionalism that focuses on practitioner behaviour instead of practitioner attitudes and intellectual capacity development. Sandberg and Pinnington (2009) equate professional competence with professionalism. This seems to be the case in the business rescue context because only members of accredited professional bodies (Table 2) are allowed to shoulder business rescue tasks. Deverell (2021) examines the role of a professional perspective in crisis management, given the need for status and improved power dynamics among practitioners.

Van De Camp, Vernooij-Dassen, Grol and Bottema (2004: 696) contend that professionalism is a multidimensional construct. There is no agreement on how to define professionalism (Arnold, 2002). Evetts (2003) analyses professionalism from a normative value system and ideological power occupation to motivate and facilitate occupation improvement. Evetts (2000: 397) considers professionalism as an evolved practice construct from occupations that are based on technical and articulation knowledge. These studies tend to examine professionalism in isolation of accreditation and competency. The studies deal with the subject professionalism within a specific case of institutional arrangement instead of the unique MPB context of SA. In this instance, professionalism is defined around control and power dynamics in an institution.

The fundamental idea is that competencies must be taught to achieve professionalism. To this end, Montazemi, Siam and Esfahanipour (2008) emphasise specialist knowledge and skills as the critical drivers of professionalism. It has been noted that teaching professionalism is less formal, and that professionalism is a learned behaviour (Henderson, Jackson, Simmons \& Edwards, 2012; Wagner, 2012). These arguments are premised on professionalism as a principle of ethics. Learning professionalism may be complicated within the MPB setting, and the advocacy for esoteric skills and knowledge ignores professionalism as a practitioner's essence of being in an occupation discipline.

Studies before 2004 show conflicting definitions of professionalism, and some authors view professionalism as a component of ethics (Shafer, 2002: 272). Making professionalism a component of ethics presupposes that teaching ethics results in training practitioners in professionalism. Other authorities link humility and honesty to professionalism, so professionalism is absent whenever honesty and humility are non-existent (Bartels, Pruyn, De Jong \& Joustra, 2007; Henning, Ram, Malpas, Sisley, Thompson \& Hawken, 2014; Howard, 2007). Van De Camp et al. (2004) demonstrate that professionalism has three dimensions, namely interpersonal (working towards proper, fit conduct with clients and colleagues), public (fulfilling the demands placed on the profession), and intrapersonal (being able to meet the demands of the profession). It is unclear which of these dimensions apply to the professional bodies and their members servicing the business rescue occupation. The concept of professionalism appears to undergo changes over time and competence-based curriculum become an option in enhancing an occupation's professionalisms (van Mook et al., 2009)

Evans (2011: 855) contends that professionalism has behavioural dimensions (what practitioners perform at work and speaks to the work processes, procedures, work outputs, and competence), attitudinal dimensions (attitudes that considers practitioner perception, assessment, and motivation to work), and intellectual dimensions (practitioners' knowledge structure, understanding, and application). Once again, differences in the construction of professionalism are evident. The question worth asking is "which construction of professionalism should apply to the multiple professional setting in South Africa?" 
We agree with the perspective that professionalism is about a practitioner's essence of being at a workplace. The practitioner's essence of being perspective emphasises what practitioners do in their working life. In the working life of an expert, we expect experts to develop relationships, deploy improved tools and technology, and create knowledge structures, such as required services, codes governing practice behaviour, and the quality of service or work output.

Table 2: Classes of licensed BRPs as of 30 September 2020

\begin{tabular}{|c|c|c|c|c|}
\hline & \multicolumn{4}{|c|}{ Licence class } \\
\hline Professional body & Total & Junior & Senior & $\begin{array}{l}\text { Experience } \\
\mathrm{d}\end{array}$ \\
\hline Association of Chartered and Certified Accountants (ACCA) & 2 & 2 & & \\
\hline The Chartered Institute of Management Accountants (CIMA) & 6 & 3 & & 3 \\
\hline Cape Law Society (CLS) & 7 & 5 & & 2 \\
\hline The Institute of Accountants in Commerce (IAC) & 6 & 4 & 0 & 2 \\
\hline The Institute of Business Advisors Southern Africa (IBASA) & 7 & 2 & 3 & 2 \\
\hline The KwaZulu-Natal Law Society (KZNLS) & 5 & 3 & 1 & 1 \\
\hline The Law Society of the Northern Provinces (LSFS) & 3 & 3 & & \\
\hline The Law Society of the Northern Cape (LSNP) & 20 & 12 & 4 & 4 \\
\hline The South African Institute for Business Accountants (SAIBA) & 20 & 16 & 1 & 3 \\
\hline SAICA & 98 & 35 & 36 & 27 \\
\hline $\begin{array}{l}\text { The Southern African Institute of Professional Accountants } \\
\text { (SAIPA) }\end{array}$ & 15 & 11 & 2 & 2 \\
\hline The Legal Practice Council of South Africa & 50 & 31 & 11 & 8 \\
\hline SARIPA & 77 & 53 & 16 & 8 \\
\hline BRA-SA & 43 & 18 & 8 & 17 \\
\hline Total classified licensees as of 30 September 2020 & 359 & $\underline{198}$ & $\underline{82}$ & $\underline{79}$ \\
\hline Total classified licensees as of 30 September 2019 & $\underline{199}$ & $\underline{99}$ & $\underline{52}$ & $\underline{48}$ \\
\hline Practitioners not linked to a PB as of 30 September 2019 & $\underline{\underline{\underline{264}}}$ & $\underline{\underline{148}}$ & $\underline{\underline{52}}$ & $\underline{\underline{69}}$ \\
\hline Percentage (30 September 2020) & $100 \%$ & $55,15 \%$ & $\underline{\underline{22,8 \%}}$ & $22,05 \%$ \\
\hline
\end{tabular}

Source: A research synthesis of CIPC BRP registration list as of 30 September 2020.

\section{Problem statement}

Text Box 1 highlights complaints to the CIPC and shows unacceptable acts perpetrated by BRPs. The CIPC has since worked with PBs to develop the business rescue CPD policy (CIPC, 2020). The following questions are worth asking: How has professionalism been constructed among BRP-supplying PBs? Does the constitution of the business rescue CPD policy lead to shared professionalism among practitioners from different PBs? There is no consensus on the meaning of professionalism. Consequently, the construction of professionalism must be understood among the BRP-supplying PBs so that the public can understand what professionalism means within the BRP occupation. Professional bodies are institutions that can enact practices (Hwang \& Colyvas, 2011). The lack of consensus on professionalism is bound to affect the criteria of professional standards that can direct the BRPs' work and mitigate against unprofessional acts (Text Box 1).

The current exploratory study sought to take the first step to document constructed professionalism and build mechanisms to direct the BRP professional accreditation regime. The unprofessional acts cited in Text Box 1 read together with the business rescue CPD policy, show that professionalism is lived in every occupation as a practitioner's essence of being in a work context. Practitioners develop professionalism, and it cannot be enforced as a performance contract from a regulatory body (Evans, 2011).

\section{Research design}

Yin (2018) contends that research purpose and questions are the starting points to formulate a research design. The study explored the construction of professionalism within the work of BRPs. The professional bodies supplying practitioners are thirteen, and only four of them contribute about 81 per cent of the currently licensed practitioners. This exploration precedes the development of a professional 
accreditation framework (including a certification) that supports the intents of the Companies Act (Act No 71 of 2008). Firstly, we interviewed (semi-structured) the dominant PBs' representatives to document the professionalism theme from their perspective. This approach is premised on the institutionalist perspective on professional work and existential ontology (Muzio, Brock, \& Suddaby, 2013; Sandberg \& Pinnington, 2009). Interviews with the representatives of PBs were complemented by content analysis of the four CPCs from the four PBs. The CIPC's business rescue CPD policy requires accredited PBs to meet out sanctions against their members for misconduct. The disciplinary regime for a PB is contained in the enabling law or CPC.

\section{Text Box 1: Signs of unprofessional acts from engaged BRPs}

Complaints raised with the regulator (CIPC) were concerning:

- abuse of power, position, and control

- practitioners were accepting irrecoverable corporate assignments

- unjustifiably high fees charged

- inadequate communication with business rescue companies

- $\quad$ non-compliance with the timelines of the Companies Act (Act No 71 of 2008)

- failure to operate within the terms of the approved business rescue plan

- business rescue costs increased the cost of liquidation

- inclination towards liquidation option instead of business rescue as liquidation is well understood by the current practitioners.

Actual complaints received by the regulator were regarding:

- dishonest in all business rescue matters (fees and claims) with no regard for creditors

- undisclosed contents of the business rescue file

- $\quad$ biased because of conflict of interest between being the attorney of record and the BRP on the relevant assignment

- fraudulently signed documents as clients never even see the affidavits/paperwork that their signatures are found on refusal to take calls from clients

- $\quad$ unqualified administration staff in BRP offices used to discuss matters with clients

Source: Adapted from the CIPC (2013). Do all answers rest in the skill set of the business rescue practitioner?

The qualitative content analysis of the four CPCs was followed by a content analysis and mapping of the literature on professionalism. We analysed scholarly literature to gauge the extent to which the PBs' construction of professionalism is supported by international literature and to respond to the second research question. Table 3 summarises the research design, as complemented by a detailed description of the design elements.

In attempting to answer the research questions, we were conscious of our own beliefs, philosophical inclinations, and operational values. These assumptions influenced how the research was conducted. The researchers' ontological stance embraced the researchers' views on the nature and spirit of the investigative activity and reality. The researchers investigated a socially constructed phenomenon in the MPB landscape. The MPB setting creates a reality that depends on the actors in the business rescue and other incidental. Therefore, we assumed that the practitioners supplying PBs contribute to the notions of professionalism through their participation in the CIPC's business rescue liaison committee. We sought to establish recurring mentions of professionalism themes. Our research curiosity was to explore the construction of professionalism as the basis to ground the development of a professional accreditation framework. The incoherent construction pointed us to the need for a pragmatic formation of the investigation process. The business rescue CPD policy demonstrates the importance of professional competence and requires accredited PBs to organise and monitor CPD for their members.

Researchers' theory of knowledge (epistemology) encapsulated how one can discover underlying principles about social phenomena and demonstrate knowledge (Wahyuni, 2012: 69). Notions of professionalism are bound to have subjective meanings, and we focused on the details of the situation as we attempted to understand the reality behind the pieces of data obtained from different sources. The details are with representatives of the PBs and other official documents addressing professional standards matters. Our personal experience with a business failure and the training of graduates seeking 
professional certification ignited our interest in the phenomenon. As academics and experienced business rescue consulting, we prefer realistic regulatory regime directing practices. We designed data-gathering methods to moderate against possible biases arising from our background.

\section{Research methods}

The research design followed in this current work is summarised in Table 3. The nature of the research question dictates the use of qualitative research procedures. Qualitative research procedures are apt to unearth and develop insights into the phenomenon under study, primarily when the phenomenon is poorly understood (Kolsaker, 2008: 515; Yin, 2018). Professionalism is poorly defined for meaningful application to the BRP occupation. Therefore, qualitative methods were deemed suitable to explore the construction of professionalism. The study had four components to it. The first component was interviews with member services managers/CEOs of the four PBs supplying $81 \%$ of registered BRPs. The interviews were guided by an interview instrument (semi-structured) that was shared with the informants before the day of the virtual meeting. The representatives of the PBs completed the data collection instruments to gauge the scope of the study. One of the researchers scheduled a virtual session, which lasted 2 hours, to discuss the informants' responses in the data collection instrument and other documents issued by the professional body. The instrument covered aspects such as the existence of a CPC, support provided to the members serving as BRPs, a professional development regime, a disciplinary and sanctions regime, the scope of professional services rendered, higher education courses offered to trainees, and the definition of professional responsibilities. The responses captured from the informants are summarised in Table 4, as complement by empirical responses from the completed data collection instrument.

Table 3: Research design

\begin{tabular}{|c|c|}
\hline Component & Description \\
\hline Problem & $\begin{array}{l}\text { There are conflicting and incoherent applications of professionalism among BRP-supplying } \\
\text { PBs. }\end{array}$ \\
\hline Research question & How should professionalism be constructed for BRPs in an MPB setting? \\
\hline Context & $\begin{array}{l}\text { The regulated BRP regime emerged in the SA setting after the promulgation of the Act. BRPs } \\
\text { drawn from multiple PBs can apply for practitioner licences. The CIPC has noted } \\
\text { unprofessional acts perpetrated by the BRPs. The socialisation of BRPs from different PBs is } \\
\text { not the same, and therefore, the construction and application of professionalism can vary. }\end{array}$ \\
\hline Propositions* & $\begin{array}{l}\text { Increased interest in professionalism has not been accompanied by a coherent construction and } \\
\text { application of professionalism. } \\
\text { Service standards and tasks dictate the notions of professionalism and can be used to manage } \\
\text { the fluidity of the construct in a MPB setting. }\end{array}$ \\
\hline Phenomenon investigated & Business rescue practitioner professionalism \\
\hline $\begin{array}{l}\text { Unit of observation and } \\
\text { analysis }\end{array}$ & $\begin{array}{l}\text { Phrases used in the CPCs and scholarly literature on professionalism. Responses from } \\
\text { representatives of PBs. }\end{array}$ \\
\hline Methodology & $\begin{array}{l}\text { Constant comparison approach using semi-structured interviews with representatives of PBs } \\
\text { and a search of scholarly literature. }\end{array}$ \\
\hline $\begin{array}{l}\text { Logic linking the data to the } \\
\text { propositions }\end{array}$ & $\begin{array}{l}\text { Practitioners embrace a sense of being in a workplace. BRPs can construct professionalism to } \\
\text { gain a practitioner essence of being in the business rescue occupation. A practitioner's essence } \\
\text { of being can be gained from the needs served and tools used to serve. Practice tools emerge } \\
\text { from institutions serving the interests of practitioners. Practitioners use CPCs and ethics to } \\
\text { discern acceptable standards because the CPC should reflect a practitioner's essence of being at } \\
\text { a workplace and within the community of practitioners. Sensemaking, premised on a } \\
\text { practitioner essence of being in an occupation, should help the researcher investigate and } \\
\text { document the construction of professionalism. }\end{array}$ \\
\hline $\begin{array}{l}\text { Criteria for interpreting the } \\
\text { findings }\end{array}$ & $\begin{array}{l}\text { The constant comparison approach creates themes that show emerging notions of } \\
\text { professionalism and their relationship to the professional accreditation regime. }\end{array}$ \\
\hline $\begin{array}{l}\text { Source: adapted from Yin, } \\
\text { publications Limited. }\end{array}$ & K. (2018). Case study research and applications: Design and methods ( $6^{\text {th }}$ Ed). London: Sage \\
\hline
\end{tabular}

We complemented the interview results with content analysis of the CPC and policy statements published by the four PBs. The content analysis of the CPCs and published policy statements established evidence of common themes used by the four dominant PBs in the BRP space. The relevance of the publicly available documents was confirmed during the semi-structured interview with representatives of the four PBs. We used an iterative process to classify statements reflecting notions of professionalism. The emerging notions of professionalism or phrases were used to do a literature search in the third component 
of the study. We examined the policy statements appearing on the selected PBs' websites for specified thematic content or other professionalism expressions. This consideration of thematic content was necessary to establish consistency between a PB's policy statements and the associated CPC. The results of this process are summarised in Table 5 .

The third component dealt with document content analysis of the literature on professionalism. We selected literature from databases with a wealth of scholarly literature on professionalism published from 2005 to 2020. The qualitative content analysis of scholarly literature provided us with an abundance of publications on the subject and an opportunity to interrogate professionalism as perceived in the international community within economics, law, and management. The search of scholarly literature and content analysis occurred over eight months. The choice of the period 2005-2020 was informed by the fact the CIPC should have considered the professionalism construct that was most recent (five years old or less) to inform regulated BRPs when the Act was promulgated in 2008 and implemented on 1 May 2011.

The third component of the study proceeded in two phases to achieve the necessary rigour and attach more context to the interview results (Table 4). We studied literature to discern notions of professionalism cited in the definition and accounts of the concept in each selected article. We then scrutinised the notions of professionalism using the constant comparison procedure to uncover the themes within the identified essentials of professionalism. The results are shown in Table 6. The study of literature was to help ascertain if the professional bodies notion of professionalisms was consistent with what was covered in the scholarly work.

The fourth component of the study was to integrate the results of the preceding study components to advance a framework for the construction, investigation, and documentation of occupation professionalism. The pragmatic framework is an important output of this study and provides a foundation for future research work. The MPB could have its own ways of constructing professionalism and those ways need to be structured. An integrated framework was needed to help the accredited bodies converge in their construction of notions of professionalism. The convergence point targets a BRP professional accreditation framework. The validation of the notions of professionalism can be expected to occur through the adoption of a professional accreditation framework. The present study did not validate the various notions of professionalism.

The literature quest entailed searching in the EBSCOhost and the JSTOR databases for articles published from 2005 to 2020. EBSCOhost and JSTOR are multi-disciplinary digitised libraries with an abundance of peer-refereed work. The business rescue occupation attracts practitioners from different disciplines. Scopus and Web of Science databases were not used because these are indexing and citation databases that focus on international journals. The search headings were premised on the results identified in the first and second components of the study. The topics we identified in the interview results with informants from the four PBs helped shape the search topics. The CPC's interview results, and content analysis revealed what PBs envisage practitioners to acquire through learning and development processes.

The search headings, therefore, included 'professionalism and attitude', 'professionalism and independence', 'professionalism and ethics', 'professionalism and identity, 'professionalism and honesty, 'professionalism and commitment', 'professionalism and education, 'professionalism and integrity', 'professionalism and competence', 'professionalism and objectivity, 'professionalism and services', 'professionalism and responsibility, 'professionalism and altruism', 'professionalism and humanism', 'professionalism and regulation', 'professionalism and probity', 'professionalism and confidentiality, 'professionalism and values', 'professionalism and education, and 'professionalism and judgement'. This search process yielded the articles in the bibliography and assembled as supplementary materials to this write up.

\section{Data analysis after coding}

The coding of the notions of professionalism provided ground to examine possible themes of professionalism using the constant comparison approach (Kolb, 2012: 84). During the first component of the study, we compared data from the interviews. We asked questions about what value information was concerning the CPCs and policy statements or enabling legislation. We identified different feature categories (notions) and magnitudes from the data. The constant comparison approach entailed an 
iterative aspect process of scrutinising and comparing diverse notions of professionalism from different informants, CPCs, and scholars to provide emerging themes. The emergence of a theme was evident from recurring examples across data. We then examined the emerging themes in the literature in relation to the results of the interviews with $\mathrm{PB}$ representatives and the content analysis of the existing CPCs of the four PBs used in the BRP process. The representatives of the PBs and the researchers discussed discrepancies in the CPCs to examine how professionalism should be constructed in the BRP space. The results are in Table 7. We tested whether an emerging picture of professionalism was valid and whether additional aspects should be explored and added during this process. There was no need to add other informants from other PBs as no new notions of professionalism would have emerged.

\section{Results and discussion}

Professionalism and associated elements from interviews

Different continents have different approaches to professionalism, as evident in the overemphasis of character traits of professions in the United States instead of professional behaviour and attitudes (Van Mook et al., 2009). Trait theory has thrived side by side with the social closure strategies that advocate for professional occupations to demonstrate professionalism through (1) exercising self-control as exercised through autonomy, collegiality and exceptional knowledge and expertise (Bell \& Cowie, 2001); (2) commanding esoteric expertise learned through prolonged training after high school (Freidson, 2001); (3) performing professional tasks that have a social value (Pareto, 2017); (4) admission members seeking to influence notions of social value (Askary, 2006); and (5) using ethical codes to regulate professional practice (Wright, 2008).

Because of the recognised continental differences in the construction of professionalism in the literature, we held interviews with representatives of four PBs whose members serve as BRPs. Table 4 presents the unpacked results of the interviews with the representatives of four PBs. The interviews show that the BRP occupation lacks a specific qualification with learning outcomes addressing a BRP service delivery package and tasks. The knowledge base and structure are likely to disintegrate among the different BRP-supplying PBs. However, we noted that the PBs had initiated efforts to offer short courses as part of CPD events. The short courses are non-credit bearing and do not contribute to certificates of competence.

The TMA's SA chapter distinguishes itself as the only PB whose members focus on BRP-related work. The other PBs offer BRP-related services along with other services as defined in their respective CPCs. The SARIPA members were historically known for liquidation services. Because BRP-related work is in addition to the other services offered by PBs' members, the PBs have worked on a policy that encourages collaboration among the members of various PBs to offer and enforce uniform CPD events (CIPC, 2020). The common CPD events present an opportunity to practitioners to take a step of faith to develop an integrated professional accreditation framework.

The CPD events are designed to develop practitioners' knowledge of the BRP field and its tools. The selected PBs relies significantly on practice notes from the CIPC (the regulator) and have not developed practice tools to enhance members' practice standards. For example, there was no mention of an engagement letter and business rescue plan as practice tools. Published training materials for learning and development are non-existent. Those interviewed battled to refer the researchers to a textbook relevant to the BRP discipline. The BRP discipline continues to be treated like any other business advisory service in the SAICA's member handbooks.

The accountancy and legal professions have three-year traineeship requirements for candidates seeking professional certification. The trainees who enter traineeship agreements gain practical training within legal or accountancy practice firms. The practice firms in these fields do not concentrate on BR services. The value of developing pipeline talent through mentorship contracts was acknowledged but has not been adequately extended to the BRP occupation. The list of licensed BRPs from different PBs is accessible. However, no attempts have been made to link trainees to licensed BRPs to be mentored on BRP matters. This situation is likely to limit the development of a pipeline talent in BRP matters. The absence of a mentorship arrangement could be compounded by the acknowledged lack of a competency framework from the PBs providing learning outcomes for BRPs. 
The selected PBs lack established standards and practices to manage and control the quality of work expected from BRPs. The legislated checks and balances linked to stakeholder participation and the need for an aggrieved party to petition the high court in instances of practitioner misconduct are relied on. The four PBs contacted do not provide a peer review mechanism for practitioners working on a business rescue assignment. The CIPC commands inadequate capacity to do inspections of BR engagements performed by licensed practitioners. This is unlike the regulator of auditors and attorneys. Those interviewed noted that the CIPC is the regulatory body for the licensed BRPs and may be required to undertake quality control tasks regarding the work of licensed BRPs.

PBs have adopted different processes of professional socialisation (the acquisition of values, attitudes, skills, and knowledge) relevant to BRP culture. The process ranges from drawing members from accredited teaching faculties at recognised higher education institutions to CPD events to experiential training. Two PBs contacted use short courses (CPD events) as a mechanism for practitioners' socialisation relevant to BRP work. CPD events for BRPs' socialisation do not equate to socialisation during higher education training at accredited teaching faculties in higher education institutions.

Members of two PBs of the four major professional bodies concentrate on liquidation and business rescue as their unique area of work. The legal and accountancy PBs embrace the work done by the SARIPA, including bankruptcy and insolvency, and TMA-SA as business advisory services. The situation diminishes the uniqueness of the selling proposition of the practitioners from the accredited bodies.

\section{Professionalism and associated essentials from codes of ethics}

There is representative literature on how to analyse CPCs. Notably, Gaumnitz and Lere (2002) investigated the content of CPCs for professional organisations representing the economics, law and management disciplines of accountancy, human capital, computer information technology, risk management, marketing and sales, operations management, and real estate. Gaumnitz and Lere (2004) built on their 2002 study to formulate a systematic framework for analysing CPCs using a numerical presentation to reflect six attributes of CPCs. These attributes of CPCs pertain to thematic content, tone, and structural form (level of detail and shape). This study is interested in substance over the structural forms of professional codes of conduct and PBs' policy statements that impact occupation practice. We employed centring resonance and textual analysis. Resonance and textual analysis use linguistics theory to assess main concepts, their influence, and their interrelationships (Canary \& Jennings, 2008; Dooley, 2016). The centring resonance and textual analysis is a transcript analysis method that can be applied to hefty quantities of printed text and transcribed dialogues (Corman et al., 2002). Centring resonance and textual analysis differ from the conventional word occurrence-based approach to the text. The centring resonance and textual analysis employ ordinary language processing abilities to formulate a model of text (Barbosa, Freitas, \& Ladeira, 2017).

Table 5 presents the results of the analysis of the four CPCs and explores whether qualitative analysis of the four CPCs shows common values. This also enabled us to establish how individual PBs have used the CPCs to frame professionalism. We found that three of the PBs do not refer to corporate turnaround or business rescue as a core area of service for their members; their scope of services tends to include services other than BRP services. The PBs have made no attempts to reference the legislated rescue requirements in their respective CPCs. In addition, matters regarding the professional appointment, acceptance, and termination of $\mathrm{BR}$ engagements are not explicitly highlighted to address unprofessional acts like those in Text Box 1. None of the four CPCs analysed allows practitioners specific discretion powers regarding professional fee determination.

Fundamental ethical principles for professional conduct covered in the analysed CPCs included integrity, fairness, honesty, confidentiality, technical competence, and independence. Yiu (2008) contends that professional ethics are linked to professionalism as standards of professional behaviour. Therefore, professional ethics go beyond the legal and individual moral standards to embrace tort (negligence) law evident in the requirements for competence and duty of due care. The reviewed CPCs emphasise social values, enhancing trust by avoiding conflict of interests, and professional responsibilities, such as collaboration, self-regulation, and mutual respect.

It is evident from Table 5 that professionalism within an occupation is constructed with reference to work outputs, the work done, practices shouldered, attitudes in dealings with others, and intellectual 
underpinnings, such as knowledge base, structure, acquisition, degree of evidence-based reasoning, comprehensive understanding of knowledge, and build-in problem-solving mechanisms. The notions of professionalism as constructed from Table 5 point to the need for professionalism in every occupation. Professionalism comes to life whenever practitioners shoulder work practices to provide a defined work output or service. All four CPCs offer a scope of professional services. This finding is consistent with Evans's (2011: 855) contention that professionalism is about a practitioner's "essence of being" in a work context. Ethics can, therefore, be seen as an ingredient of professionalism, and the latter should not be treated as an ethical principle.

\section{Professionalism and its essentials from the selected literature}

We completed the search for literature using key phrases to access the relevant literature. We qualitatively analysed the contents of the selected articles. We examined the references of the articles chosen for missing scholarly articles. The selected articles were further sorted using an inclusion criterion that required the selected article to be relevant to the field of economics, law, and management. Articles relating to health professionals, engineering, and architecture were excluded. In addition, the selected articles had to contain a description or a definition of professionalism. We were able to identify distinct definitions and meanings attached to professionalism and its essential elements. The adopted selection process resulted in 192 scholarly articles related directly to the aim of our study and are included in the bibliography. The list of references only contains sources that are cited in the text write up. Descriptions in the selected literature are referring to 'integrity and competence' as 'values in professionalism' compelled us to code 'competence' and 'integrity as distinct notions of professionalism.

Content analysis of the selected articles established that scholars lack a shared definition of the notion of professionalism. Several articles listed professionalism as a principle of a code of ethics. The explanations offered for the nature of professionalism are diverse in their cited components and their descriptive details. Instances in which professionalism was defined in a sentence concerning CPCs or ethics were noted. Other scholars offered more than four components of professionalism. We found only 117 cases where constituent notions of professionalism were covered in the articles. In 75 cases, the constituent notions of professionalism were taken for granted and had to be inferred from the context in which they were raised. There are instances where notions of professionalism were taken for granted. We found less than explicit definitions of professionalism in articles dealing with professional ethics education as they assumed a shared understanding of professionalism as a principle of professional, ethical conduct.

Table 4: Synthesised results from the semi-structured data collection instruments

\begin{tabular}{|c|c|c|c|c|}
\hline Item & Law Society & SAICA & SARIPA & TMA-SA \\
\hline $\begin{array}{l}\text { Contents of current } \\
\text { syllabus and its relevance } \\
\text { to BRP. } \\
\text { [Dealings with the PB: } \\
\text { What is the knowledge } \\
\text { structure, the } \\
\text { understanding and } \\
\text { acquisition of esoteric } \\
\text { knowledge and skills] }\end{array}$ & $\begin{array}{l}\text { Legal aspects of } \\
\text { business rescue are } \\
\text { addressed in } \\
\text { courses dealing } \\
\text { with business } \\
\text { association laws. }\end{array}$ & $\begin{array}{l}\text { Accredited } \\
\text { universities offer } \\
\text { specific } \\
\text { accountancy } \\
\text { qualifications. No } \\
\text { content on business } \\
\text { rescue. }\end{array}$ & $\begin{array}{l}\text { No qualification } \\
\text { because } \\
\text { membership } \\
\text { open to more } \\
\text { than one } \\
\text { specialisation. } \\
\text { Reference made } \\
\text { of the University } \\
\text { of Pretoria's (UP) } \\
\text { one-year } \\
\text { Certified Rescue } \\
\text { Analyst } \\
\text { qualification }\end{array}$ & $\begin{array}{l}\text { No specific } \\
\text { qualification offered } \\
\text { by the university. } \\
\text { Reference made to the } \\
\text { Certified Rescue } \\
\text { Analyst qualification } \\
\text { provided by UP }\end{array}$ \\
\hline $\begin{array}{l}\text { Unique selling } \\
\text { proposition from the PB. } \\
\text { [Dealing with others in a } \\
\text { distinguishable way] }\end{array}$ & $\begin{array}{l}\text { Legal services: } \\
\text { Litigation, notary, } \\
\text { and conveyancing. }\end{array}$ & $\begin{array}{l}\text { Chartered } \\
\text { accountancy } \\
\text { focussing on audit } \\
\text { assurance, tax, and } \\
\text { business advisory. } \\
\text { Business rescue } \\
\text { falls under business } \\
\text { advisory }\end{array}$ & $\begin{array}{l}\text { The SARIPA } \\
\text { reckons to be the } \\
\text { largest PB in SA } \\
\text { in the BR } \\
\text { occupation and } \\
\text { participates } \\
\text { insolvency and } \\
\text { restructuring }\end{array}$ & $\begin{array}{l}\text { Business rescue and } \\
\text { BR services. Affected } \\
\text { parties preferring } \\
\text { TMA-SA }\end{array}$ \\
\hline
\end{tabular}




\begin{tabular}{|c|c|c|c|c|}
\hline Item & Law Society & SAICA & SARIPA & TMA-SA \\
\hline & & & $\begin{array}{l}\text { activities } \\
\text { worldwide. }\end{array}$ & \\
\hline $\begin{array}{l}\text { Distinguished services } \\
\text { offered by the PB. } \\
\text { [Dealings with work tasks } \\
\text { and services] }\end{array}$ & $\begin{array}{l}\text { Legal services as } \\
\text { defined in the legal } \\
\text { practice } \\
\text { Members } \\
\text { undertake work } \\
\text { according to a } \\
\text { client's brief. }\end{array}$ & $\begin{array}{l}\text { Auditing, } \\
\text { accounting, } \\
\text { independent } \\
\text { review, } \\
\text { management } \\
\text { consulting, and } \\
\text { financial } \\
\text { management. } \\
\text { Members undertake } \\
\text { work according to } \\
\text { the letter of } \\
\text { engagement and } \\
\text { plan }\end{array}$ & $\begin{array}{l}\text { The SAQA } \\
\text { recognises } \\
\text { SARIPA for its } \\
\text { insolvency and } \\
\text { rescue services. } \\
\text { Members have } \\
\text { been appointed } \\
\text { in BRP matters to } \\
\text { date. }\end{array}$ & $\begin{array}{l}\text { Members off BRP } \\
\text { services. The BRA-SA } \\
\text { is a professional } \\
\text { association and does } \\
\text { not take on work done } \\
\text { by lawyers, } \\
\text { accountants, auditors, } \\
\text { etc., outside the BR } \\
\text { process. Members } \\
\text { undertake work } \\
\text { according to a rescue } \\
\text { plan }\end{array}$ \\
\hline $\begin{array}{l}\text { The PB's support to } \\
\text { members serving as BRPs. } \\
\text { [Dealings with the PB] }\end{array}$ & $\begin{array}{l}\text { Relies on practice } \\
\text { notes issued by the } \\
\text { CIPC. Ensuring } \\
\text { good standing of } \\
\text { members to meet } \\
\text { accreditation } \\
\text { requirements. }\end{array}$ & $\begin{array}{l}\text { CPD help members } \\
\text { gain insights into } \\
\text { BRP practices, } \\
\text { prepares a letter of } \\
\text { good standing for } \\
\text { the member to } \\
\text { obtain BRP licence, } \\
\text { disciplinary for } \\
\text { misconduct, } \\
\text { monitoring the } \\
\text { CPD activities. }\end{array}$ & $\begin{array}{l}\text { Regular webinars } \\
\text { on BR practices, } \\
\text { practice notes } \\
\text { and case law } \\
\text { updates. }\end{array}$ & $\begin{array}{l}\text { There are numerous } \\
\text { practice notes } \\
\text { covering topics that } \\
\text { range from initiating } \\
\text { business rescue, } \\
\text { reasonable prospect to } \\
\text { the charging of fees. } \\
\text { Tools for planning, } \\
\text { reporting to court and } \\
\text { CIPC emerge from } \\
\text { CIPC practice notes. }\end{array}$ \\
\hline $\begin{array}{l}\text { Practice tools available to } \\
\text { members serving as BRPs. } \\
\text { [Dealing with work tasks: } \\
\text { How services are rendered] }\end{array}$ & $\begin{array}{l}\text { The CIPC- } \\
\text { developed practice } \\
\text { notes and circulars. } \\
\text { Rescue plans as per } \\
\text { the Act. }\end{array}$ & $\begin{array}{l}\text { The CIPC- } \\
\text { developed practice } \\
\text { notes and circulars. } \\
\text { No specific tools } \\
\text { used as in the case } \\
\text { of audit assurance. } \\
\text { Rescue plan as per } \\
\text { the Act. }\end{array}$ & $\begin{array}{l}\text { The members } \\
\text { rely on the CIPC- } \\
\text { developed } \\
\text { practice notes } \\
\text { and circulars. } \\
\text { Rescue plan as } \\
\text { per the Act. }\end{array}$ & $\begin{array}{l}\text { CIPC-developed } \\
\text { practice notes and } \\
\text { circulars. Members } \\
\text { prepare rescue plans } \\
\text { to guide BRP } \\
\text { assignments. }\end{array}$ \\
\hline $\begin{array}{l}\text { Support training } \\
\text { materials are known and } \\
\text { used in the development } \\
\text { of members practising as } \\
\text { BRPs. [Dealing with the PB: } \\
\text { Knowledge understanding } \\
\text { and acquisition] }\end{array}$ & $\begin{array}{l}\text { Case law book, } \\
\text { relevant legislation. }\end{array}$ & $\begin{array}{l}\text { Members use any } \\
\text { available course } \\
\text { materials used in } \\
\text { CPD events. }\end{array}$ & $\begin{array}{l}\text { Detailed courses } \\
\text { presented at the } \\
\text { University of } \\
\text { South Africa } \\
\text { (UNISA) and UP. }\end{array}$ & $\begin{array}{l}\text { There are no specific } \\
\text { recommended } \\
\text { textbooks. There is a } \\
\text { certified rescue } \\
\text { analyst course that } \\
\text { BRA-SA developed } \\
\text { with UP. A good book } \\
\text { is "Corporate } \\
\text { Restructuring: From } \\
\text { Cause Analysis to } \\
\text { Execution by David } \\
\text { Vance". }\end{array}$ \\
\hline $\begin{array}{l}\text { Established training } \\
\text { contracts and mentorship } \\
\text { on BRP-specific matters. } \\
\text { [Dealing with work tasks } \\
\text { and services: Development } \\
\text { of skills to the quiddity of } \\
\text { BRP] }\end{array}$ & $\begin{array}{l}\text { No mentorship or } \\
\text { traineeship } \\
\text { agreements } \\
\text { specifically } \\
\text { addressed } \\
\text { matters. }\end{array}$ & $\begin{array}{l}\text { None. The SAICA } \\
\text { has a register of } \\
\text { BRPs, which is } \\
\text { published, and } \\
\text { trainees can use it } \\
\text { to establish contacts } \\
\text { with accomplished } \\
\text { membership for } \\
\text { mentoring. }\end{array}$ & $\begin{array}{l}\text { Current } \\
\text { mentorship is not } \\
\text { formalised } \\
\text { because aspiring } \\
\text { young BRPs are } \\
\text { welcome to the } \\
\text { SARIPA for } \\
\text { assistance to } \\
\text { identify } \\
\text { mentoring }\end{array}$ & $\begin{array}{l}\text { No formal mentorship } \\
\text { programme. } \\
\text { Mentorship occurs } \\
\text { with the UP course } \\
\text { that covers business } \\
\text { finance, tax, law, } \\
\text { business management, } \\
\text { and professional } \\
\text { ethics }\end{array}$ \\
\hline
\end{tabular}




\begin{tabular}{|c|c|c|c|c|}
\hline Item & Law Society & SAICA & SARIPA & TMA-SA \\
\hline & & & opportunities. & \\
\hline $\begin{array}{l}\text { Established standards } \\
\text { and practices to manage } \\
\text { and control the quality of } \\
\text { work expected from } \\
\text { BRPs. } \\
\text { [Dealing work tasks and } \\
\text { services: What is the } \\
\text { required work behaviour] }\end{array}$ & $\begin{array}{l}\text { Seeking a second } \\
\text { opinion on matters } \\
\text { in which the } \\
\text { practitioner lacks } \\
\text { competence. }\end{array}$ & $\begin{array}{l}\text { The CPC } \\
\text { (requirement 113) } \\
\text { requires that the } \\
\text { BRP not undertake } \\
\text { engagements the } \\
\text { BRP is not } \\
\text { competent to } \\
\text { perform unless the } \\
\text { practitioner obtains } \\
\text { advice and } \\
\text { assistance. }\end{array}$ & $\begin{array}{l}\text { Relies on the } \\
\text { legislated checks } \\
\text { and balances, } \\
\text { stakeholder } \\
\text { participation and } \\
\text { petitions to the } \\
\text { high court. }\end{array}$ & $\begin{array}{l}\text { None. Review occurs } \\
\text { when instances of } \\
\text { misconduct are } \\
\text { brought to the fore. } \\
\text { The BRA-SA a code } \\
\text { ethics and practice } \\
\text { standard have been } \\
\text { published. These two } \\
\text { combined with the } \\
\text { accreditation policy } \\
\text { are the key policies for } \\
\text { quality of work and } \\
\text { benchmarking. }\end{array}$ \\
\hline $\begin{array}{l}\text { Established professional } \\
\text { codes and competency } \\
\text { framework applicable to } \\
\text { BRPs. } \\
\text { [Dealings with the public, } \\
\text { clients, and others] }\end{array}$ & $\begin{array}{l}\text { Professional } \\
\text { principle and Legal } \\
\text { Professional } \\
\text { Practice Act apply } \\
\text { to attorneys and } \\
\text { advocates. }\end{array}$ & $\begin{array}{l}\text { The CPC contains } \\
\text { requirements } \\
\text { dealing with } \\
\text { business advisory } \\
\text { services. } \\
\text { Competency } \\
\text { framework exists } \\
\text { for chartered } \\
\text { accountants } \\
\text { without BRP } \\
\text { specifics. }\end{array}$ & $\begin{array}{l}\text { The PB does not } \\
\text { have a distinct } \\
\text { competency } \\
\text { framework for } \\
\text { those seeking } \\
\text { membership. }\end{array}$ & $\begin{array}{l}\text { On the website there } \\
\text { is a published code } \\
\text { ethics and practice } \\
\text { standard. The two } \\
\text { documents go } \\
\text { together with the } \\
\text { accreditation policy, } \\
\text { specifying the } \\
\text { qualifications required } \\
\text { to apply for } \\
\text { membership. }\end{array}$ \\
\hline $\begin{array}{l}\text { Established process of } \\
\text { professional socialisation } \\
\text { to acquire values, } \\
\text { attitudes, skills, and } \\
\text { knowledge. [Dealing with } \\
\text { others: Perceptions, beliefs } \\
\text { and views held; people's } \\
\text { values; and people's } \\
\text { motivation, occupation } \\
\text { satisfaction and morale] }\end{array}$ & $\begin{array}{l}\text { Training of lawyers } \\
\text { from accredited } \\
\text { faculties and } \\
\text { training firms. } \\
\text { There is a common } \\
\text { platform for CPDs } \\
\text { for lawyers. }\end{array}$ & $\begin{array}{l}\text { Training of } \\
\text { chartered } \\
\text { accountants from } \\
\text { accredited schools } \\
\text { of accountancy and } \\
\text { training firms. } \\
\text { There is a common } \\
\text { platform for CPD } \\
\text { events. }\end{array}$ & $\begin{array}{lr}\text { Short } r & \text { courses } \\
\text { offered } & \text { by } \\
\text { UNISA, the } & \text { thiversity of } \\
\text { Unitr } & \\
\text { Johannesburg } & \\
\text { and UP. No } \\
\text { limitations to } \\
\text { unstructured } \\
\text { networking } \\
\text { opportunities. }\end{array}$ & $\begin{array}{l}\text { The member } \\
\text { accreditation policy } \\
\text { refers to conferences, } \\
\text { annual BRA-SA } \\
\text { events, and the } \\
\text { Certified Rescue } \\
\text { Analyst course offered } \\
\text { by UP. These are used } \\
\text { to entrench values, } \\
\text { attitudes, and skills. }\end{array}$ \\
\hline
\end{tabular}

Source: Researcher's synthesis of data

Emerging themes from the literature and interview results

As seen in Table 6, we recognised a total of 38 constituent notions of professionalism. It is interesting to note that professional ethics, ethical conduct, technical knowledge, professional code, specialised knowledge and expertise, integrity, autonomy, commitment, standards-based work and education, and certifications were highlighted most frequently. The findings are consistent with the perspective that professionalism is about a practitioner's essence of being in an occupation (Kolsaker, 2008). The emerging themes of dealings with clients, dealings with PBs, dealings with the public and dealings with oneself resonate with the perspective of professionalism as a consideration of a practitioner gaining from a work context. The work context (not SAQA-recognised bodies) is what defines work practices and service.

The four emerging themes of professionalisms (Table 7) are linked to the different notions of professionalism reflected in Tables 4, 5 and 6 . Table 7 provides a brief description of the themes in column 3. The integration of results in Table 7 shows that professionalism is not about the professional competence that has enjoyed attention from the CIPC, which recently issued a business rescue CPD policy. In Table 5, not all aspects of professionalism are covered across the codes of professional conduct we analysed. The missing aspects led us to argue for the case for a pragmatic approach to the construction of professionalism, which is summarised in Figure 1. 
Table 5: Focus of professional codes of ethics and constitutions

\begin{tabular}{|c|c|c|c|c|}
\hline Item & Law Society & SAICA & SARIPA & TMA-SA \\
\hline Scope of professional services & $\sqrt{ }$ & $\sqrt{ }$ & $\sqrt{ }$ & $\sqrt{ }$ \\
\hline Meaning of BR practice or business rescue practice & & & $\sqrt{ }$ & $\sqrt{ }$ \\
\hline BRP tasks outlined & & & & $\sqrt{ }$ \\
\hline Integrity and honesty as ethical principles & $\sqrt{ }$ & $\sqrt{ }$ & $\sqrt{ }$ & $\sqrt{ }$ \\
\hline Objectivity as an ethical principle & $\sqrt{ }$ & $\sqrt{ }$ & $\sqrt{ }$ & $\sqrt{ }$ \\
\hline Professional competence and qualifications & $\sqrt{ }$ & $\sqrt{ }$ & $\sqrt{ }$ & $\sqrt{ }$ \\
\hline Due care and skill exercised during work & $\sqrt{ }$ & $\sqrt{ }$ & $\sqrt{ }$ & $\sqrt{ }$ \\
\hline $\begin{array}{l}\text { Professional confidentiality is given as an ethical } \\
\text { principle }\end{array}$ & $\sqrt{ }$ & $\sqrt{ }$ & $\sqrt{ }$ & $\sqrt{ }$ \\
\hline Professional behaviour and reputation & $\sqrt{ }$ & $\sqrt{ }$ & $\sqrt{ }$ & $\sqrt{ }$ \\
\hline Professional independence & $\sqrt{ }$ & $\sqrt{ }$ & $\sqrt{ }$ & $\sqrt{ }$ \\
\hline Conflict of interest discouraged to enhance trust & $\sqrt{ }$ & $\sqrt{ }$ & $\sqrt{ }$ & $\sqrt{ }$ \\
\hline \multicolumn{5}{|l|}{ Links to the legislated business rescue requirements } \\
\hline Public interest and relationship with the PB & $\sqrt{ }$ & $\sqrt{ }$ & $\sqrt{ }$ & $\sqrt{ }$ \\
\hline Links to the PB's constitution and by-laws & $\sqrt{ }$ & $\sqrt{ }$ & $\sqrt{ }$ & $\sqrt{ }$ \\
\hline Membership and subscription fees & $\sqrt{ }$ & $\sqrt{ }$ & $\sqrt{ }$ & $\sqrt{ }$ \\
\hline $\begin{array}{l}\text { Disciplinary structures, meaning of misconduct and } \\
\text { sanctions }\end{array}$ & $\sqrt{ }$ & $\sqrt{ }$ & $\sqrt{ }$ & $\sqrt{ }$ \\
\hline $\begin{array}{l}\text { Requirements for members to comply with laws and } \\
\text { regulations }\end{array}$ & $\sqrt{ }$ & $\sqrt{ }$ & $\sqrt{ }$ & $\sqrt{ }$ \\
\hline $\begin{array}{l}\text { Professional appointment and acceptance (engagement } \\
\text { letters and client briefs) }\end{array}$ & $\sqrt{ }$ & $\sqrt{ }$ & $\sqrt{ }$ & $\sqrt{ }$ \\
\hline $\begin{array}{l}\text { The discretion granted in respect of charging } \\
\text { professional fees }\end{array}$ & $\sqrt{ }$ & $\sqrt{ }$ & & \\
\hline $\begin{array}{l}\text { Members are encouraged to seek a second opinion or } \\
\text { use third parties on complex assignments }\end{array}$ & $\sqrt{ }$ & $\sqrt{ }$ & $\sqrt{ }$ & $\sqrt{ }$ \\
\hline Restricted marketing and advertising of services & $\sqrt{ }$ & $\sqrt{ }$ & & \\
\hline
\end{tabular}

Source: Researchers' synthesis of available codes of professional conduct.

The matter is not addressed explicitly in the policy and the CPC.

\section{Dealings with clients - Business rescue entities and clients}

Dealings with clients recognise notions of professionalism that help the practitioner to provide legislated services effectively. The notions of professionalism in this theme give preconditions for effective and adequate contact with a business rescue entity and its stakeholders. The notions cover the need to have a cordial relationship with the client's business rescue entity. Educating the client on rescue options and the design of plans are essential. A few other notions of professionalism within this theme are relevant to dealings with stakeholders and other team members during a rescue operation. The nature of the work practice may lead to the demonstration of notions of 'dealings with clients' when a practitioner interacts with staff at a business rescue site and enlists the help of other experts.

Dealing with clients relates to what a practitioner does during a business rescue process. Informants referred us to the uniqueness of the business rescue when one of them observed that "yes, the services provided by members in terms of business rescue are distinct from the other services provided. BRPs utilise skills learned from business advisory". We, therefore, expect the notions of professionalisms to include work processes, procedures, productivity, and skills relevant to the business rescue. A professional occupation comes into existence to render services and outputs that expertly meet clients' needs. To this end, Fatemi et al. (2018: 140) maintain that "most practitioners assume their clients prefer tax-saving strategies, even when not explicitly requested" and undertake tasks that favour clients. 
Table 6: Notions of professionalism used scholarly definitions and descriptions

\begin{tabular}{|c|c|c|c|}
\hline Public interest & 45 & Public image/prestige/reputation & 44 \\
\hline Attitudes & 31 & Professional appearance/dress code & 16 \\
\hline Public trust & 44 & Confidence & 15 \\
\hline $\begin{array}{ll}\begin{array}{l}\text { Personal } \\
\text { characteristic }\end{array} & \text { values/subjective } \\
\end{array}$ & 25 & Commitment/devotion & 77 \\
\hline $\begin{array}{l}\text { Work in the interest of clients } \\
\text { (focus) }\end{array}$ & 44 & Responsibilities & 47 \\
\hline $\begin{array}{l}\text { Professional ethics/ethical } \\
\text { conduct }\end{array}$ & 86 & Mutual recognition, courtesy, and respect & 30 \\
\hline Professional code & 80 & Standards-based work and education & 86 \\
\hline $\begin{array}{c}\text { Substance } \\
\text { knowledge }\end{array}$ of specialist & 111 & $\begin{array}{l}\text { Professional development/continual updating } \\
\text { knowledge }\end{array}$ & 36 \\
\hline $\begin{array}{lll}\text { Quality: } & \text { (dependable) } & \text { work } \\
\text { outputs } & & \end{array}$ & 45 & Evidence-based practice & 18 \\
\hline Professional abilities & 25 & Teamwork and collaboration/collegiality & 31 \\
\hline Technical competence/skills & 91 & Certification/licence & 64 \\
\hline $\begin{array}{l}\text { Technological (methods of } \\
\text { practice) }\end{array}$ & 28 & Body of practice & 16 \\
\hline Experienced and maturity & 26 & Accountability & 42 \\
\hline Objectivity & 21 & Accreditation and stringent entry requirements & 34 \\
\hline Independence & 43 & Probity & 23 \\
\hline Integrity & 73 & Honesty & 42 \\
\hline $\begin{array}{l}\text { Judgement (making decisions in } \\
\text { complex situations) }\end{array}$ & 32 & & \\
\hline Altruism/social values & 29 & & \\
\hline Client advocacy & 29 & & \\
\hline Fairness & 32 & & \\
\hline $\begin{array}{l}\text { Self- } \\
\text { regulation/policing/direction }\end{array}$ & 58 & & \\
\hline Autonomy & 101 & & \\
\hline
\end{tabular}

Source: Researchers' content analysis of selected articles published during 2005-2020.

Table 7: Emerging themes from dimensions of professionalism in Tables 4, 5, and 6

\begin{tabular}{|c|c|c|}
\hline Theme & Aspects & Descriptions \\
\hline $\begin{array}{l}\text { Dealings with the } \\
\text { associations }\end{array}$ & $\begin{array}{l}\text { Collaborating with a community of } \\
\text { experts } \\
\text { Competence and specialist } \\
\text { knowledge } \\
\text { Self-regulation and direction } \\
\text { Professional reputation } \\
\text { Continuous training and } \\
\text { development } \\
\text { Certification and licensing } \\
\text { Methods of professional practice } \\
\text { Mentoring of trainees }\end{array}$ & $\begin{array}{l}\text { The theme is about a practitioner fulfilling } \\
\text { the requirements regarding professional } \\
\text { commitments to the PB and peers in the BR } \\
\text { field. } \\
\text { This description emanates from a } \\
\text { professional body representative who } \\
\text { observed: "we approve training courses for } \\
\text { our members. Please refer to our website for } \\
\text { details of courses presented at the University of } \\
\text { South Africa and the University of Pretoria." }\end{array}$ \\
\hline $\begin{array}{l}\text { Dealings with clients to } \\
\text { provide services (work } \\
\text { tasks) }\end{array}$ & $\begin{array}{l}\text { Independent work } \\
\text { Competence, due care, and skill } \\
\text { Honesty and integrity } \\
\text { Dedication and commitment } \\
\text { Quality of outputs and services } \\
\text { Evidence-based advice } \\
\text { Trusted experts } \\
\text { Confidentiality and respect } \\
\text { Compassion and polite in } \\
\text { relationships } \\
\text { Educate clients on options available }\end{array}$ & $\begin{array}{l}\text { The theme is about a practitioner fulfilling } \\
\text { the work practice requirements of the } \\
\text { occupation's purpose, status, specific } \\
\text { nature, range, and service levels. To this } \\
\text { end, the informant pointed out that:" none } \\
\text { of our members is allowed to enter into a } \\
\text { service engagement contract without requisite } \\
\text { competencies." }\end{array}$ \\
\hline
\end{tabular}




\begin{tabular}{|c|c|c|}
\hline Theme & Aspects & Descriptions \\
\hline & $\begin{array}{l}\text { Respect clients' right of shared } \\
\text { decision making } \\
\text { Subservient self-interests }\end{array}$ & \\
\hline $\begin{array}{l}\text { Dealings with the public, } \\
\text { including government } \\
\text { and others }\end{array}$ & $\begin{array}{l}\text { Fairness and transparency } \\
\text { Trusted expert } \\
\text { Standards-based work and training } \\
\text { Mutual recognition and respect } \\
\text { Accountability } \\
\text { Submission to an ethical code } \\
\text { High level of expertise } \\
\text { Methodological and thoroughness } \\
\text { Technical competence } \\
\text { Enhancing the welfare of the society } \\
\text { Protect confidential information } \\
\text { Commitment to the contribution of } \\
\text { business to society } \\
\text { Expert authority } \\
\text { Autonomy of professional } \\
\text { associations }\end{array}$ & $\begin{array}{l}\text { The theme is about a practitioner fulfilling } \\
\text { the requirements society imposes on the } \\
\text { sanctioned occupation. As one informant } \\
\text { observed: "our members serve in the } \\
\text { capacities of insolvency and business rescue } \\
\text { practitioners. These are government regulated } \\
\text { service areas." }\end{array}$ \\
\hline Dealings with oneself & $\begin{array}{l}\text { Demonstrated maturity } \\
\text { Confidence and self-conception } \\
\text { Dress code and appearance } \\
\text { CPD } \\
\text { Value corporate renewal work } \\
\text { Unimpaired judgement } \\
\text { Professional scepticism } \\
\text { Response to stress and self- } \\
\text { awareness } \\
\text { Critical analysis }\end{array}$ & $\begin{array}{l}\text { The theme is about a practitioner fulfilling } \\
\text { the requirements to operate in the BR } \\
\text { practice field as a practitioner. To this end, } \\
\text { one of the professional body } \\
\text { representatives indicated that "CPD events } \\
\text { provide endless networking opportunities for } \\
\text { self-development." }\end{array}$ \\
\hline
\end{tabular}

Source: Researcher's synthesis of research data.

\section{Dealings with professional associations}

Dealings with professional associations constitute a theme because the CIPC requires practitioners to be members in good standing with their PBs. In terms of section 138 of the Act, a person may only be appointed as a BRP if a member is a good standing of a legal, accounting or business management PB accredited by the CIPC. The CIPC's requirement, as set out in Notice No. 2 of 2019, is that the pre-requisite to be registered as a BRP is that the person must obtain a letter of good standing from their PB. Representatives of the PBs believe a practitioner dealing with the PB is important given the CPCs and associated relational aspects.

This theme encompasses professionalism notions that pertain to pre-requisites for becoming a member of a PB and remaining in good professional standing. Staying relevant and up to date in the field is as important as gaining admission. To this end, the informants directed our attention to competency by reporting that "the competency framework contains competencies, although not specific to BRPs, that would be more applicable ensuring admission of new members". Some of the notions of professionalism in this theme relate to working with colleagues, undertaking peer review work and CPD events, and contributing to the professional reputation. Other notions within this theme cover structured dealings with colleagues. Most notions are deemed relevant as part of a practitioner's essence of being in an occupational discipline.

\section{Dealings with the public and others}

The third emerging theme puts together notions of professionalism that guide a practitioner's dealings, leading to fulfilling the requirements that society, through Parliament, places on the BRP occupation. It deals with standards-based training and work practices and a trusted expert that is not conflicted. An illustration of these notions can be found in the work of Fatemi et al. (2018: 134), who contend that "... codes of conduct apply to all members but ... practitioners, in particular, are cast in a unique role of serving the public interest with their accountability to both clients and tax agencies (among 
other stakeholders)". One of the informants remarked that: "With regards to mentoring, SAICA is investigating possible options in future to assist with mentoring." This pointed to the fact dealing with others in vital.

Public trust and interest obligate SAQA-recognised PBs to know relevant laws, to undertake practical and transparent self-regulation and to support the development of pipeline talent. Therefore, compared to dealings with the clients' theme, this theme addresses context values and requirements associated with regular professional commitments. In response to ensuring professional commitment, one of the four informants noted that "the CIPC is the regulatory body for BRPs commitments. This might be undertaken in future, depending on the CIPC's requirements". This meant that professional bodies did not have modalities to review BRP work carried out by their members to ensure adherence to the professional commitments.

\section{Dealings with oneself}

The fourth theme relates to dealings with oneself and addresses requirements that a practitioner must fulfil to operate adequately in the business rescue profession as an individual. The notion of dealing with oneself involves personal characteristics or behaviours that are deemed to impact the way an individual practitioner operates. This theme raises the role of attitudinal behaviour in professionalism as supported by Askary (2006) and Creasy (2015: 24), who argue that professional behaviours are observable actions that demonstrate the expert's appropriate behaviours modelling the appearance, attitudes, selfmanagement, and timeliness in the pursuit of service. An example of descriptions of elements of dealings with oneself are "courage, temperance or self-control, and justice-along with related moral virtues such as humility, integrity, patience, courtesy, modesty, and liberality" (Lail, MacGregor, Marcum, \& Stuebs, 2017: 696). Representatives of the PBs expressed the need for practitioner socialisation through CPD events as a vehicle that practitioners can use to gain a sense of belonging to the occupation. Two of the informants pointed to 4 June 2020 SAICA / SARIPA business rescue training event that focused on the consideration that practitioners needed to the COVID-19 pandemic effects as part of self-management."

\section{Towards pragmatic construction of business rescue professionalism construction and documentation}

The results from interviews with the selected PB representatives and content analysis of the four CPCs and scholarly literature point to professionalism construction emphasising practitioner essence of being within the occupation. The emerging dimensions of the practitioner essence of being in an MPB context require a professionalism construction and documentation framework.

Figure 1 sets out the programmatic way of constructing, investigating and documenting professionalism to achieve the practitioner essence of being within the BRP occupation. Figure 1 (reading from top to down) begins with an understanding of BRP services and tasks from regulatory requirements in a jurisdiction and the results of interviews with practitioners. Pretorius (2014) recognises the existence of a BRP legal framework used to outline BRP tasks. Purposive interpretation of regulatory requirements can be used to understand and document legislative services and tasks. Results from purposive interpretation can be complemented by the double results from interviews with members of the community of practitioners in the BRP occupation. The suggested process is envisaged to contribute to the inherent nature (quiddity) of professionalism. Occupations exist to serve needs, and fulfilling the needs creates the practitioner's essence of being.

Rajaram and Singh (2018) emphasise the importance of professional competence and confirm the efforts required to identify and develop BRPs' professional competence relevant to practitioners' work and services. The services and tasks are evident from service package objectives, tools, methods of work and work organisation. BRPs' tasks and services can be discerned from the legislative requirements and the CPCs subjected to purposive interpretation during the research process. In the present study, the BRPs' tasks and services were not confirmed by representatives of the four major PBs.

The arrows in Figure 1 show the interrelationships among different framework components. From the top-down in Figure 1, we argue that desired services dictate tasks shouldered by BRPs. These tasks and service packs should help come up with an expert BRP profile and other ingredients of the professional accreditation framework. The tasks shouldered to provide services inform professional competence, which can be used to develop learning and development resources (human capital investments) required to support professional accreditation. Professional accreditation is needed to deal 
with BRP licensing and to link BRPs to a PB. Therefore, services are required to help define the BRP discipline boundaries for accreditation and certification purposes. The desired CPD regime should fall within the defined BRP discipline boundaries.

It will be unexpected for BRP professionalism to be constructed and developed outside a professional accreditation and certification process and without defining the theory and practice claim covered by the BRP professional certification. Professional training that is informed by a professional accreditation framework and certification activities define the notions of professionalism. Professionalism founded on services, tasks, methods, expertise, and ethics becomes relevant after BRPs have claimed their ability to perform at defined standards, as articulated in the professional accreditation regime. PBs and higher education institutions can facilitate professional learning and development interventions to develop competent BRPs. Dealings with others in learning and development enhance the practitioner's essence of being in an occupation. Therefore, higher education institutions and PBs serve as critical sources of data to develop the professional accreditation regime.

\section{Conclusion}

The PBs supplying BRPs construct professionalism differently (Tables 4 and 5). We argued that professionalism is about a practitioner's essence of being in an occupation context. The differences in the construction should be understood against the background of different training backgrounds and socialisation processes of members of different PBs working in the BR space. This finding has implications for exercising professionalism in business rescue assignments. The CIPC, through its regulations and CPD policy (CIPC, 2020), advocates for professionalism in the BRP occupation. However, it remains challenging to understand, identify, construct, and document professionalism in an occupation context with the MPB landscape. Figure 1 summarises these aspects and points to integrated data collection procedures in designing a professional accreditation framework needed to enhance professionalism in the $\mathrm{BRP}$ occupation. BRPs are subject to contentions of abuse and, consequently, professional accreditation has become a pre-obligatory to strengthen professionalism.

The emerging relational perspective of professionalism as constituted by a practitioner's "essence of being" in an occupation suggests that the CIPC moves away from specialist knowledge and skills towards a practitioner's dealings with oneself, the public, PBs, and clients. Using such elucidations of professionalism lead to informed choices on professional accreditation, learning and development. The multi-relational aspects of professionalism point to the need to develop a professional accreditation framework. The integrated exploration in the present exposition supports the notion that our understanding of professionalism is fragmented if the BRP fails to link brains and hands power to tools of the trade, needs to be served by practitioners, professional behaviour, and professional attitude to others.

The article's essential contribution is to interpretatively explore the constructed meaning of professionalism as an organising framework for the MPBs shouldering BRP work. It provides a pragmatic path for the construction and documentation of professionalism (Figure 1). It also enhances the professionalism literature by exploring how the concept is understood and socially constructed within the scholarly literature and in the present non-generic context. We examined notions of professionalism within an existing MPB landscape from the perspective of a practitioner's "essence of being" in an occupation to enhance BRP professionalism in an integrated way. 
Figure 1: Pragmatic construction and documentation of professionalism

Content analysis and purposive interpretation of BRP legislative requirements and regulatory agency's practice notes

Content analysis of codes of professional conduct of BRP-supplying professional bodies; Content analysis of policy documents

Semi-structured interview with representatives of the professional body; interview to the double with practitioners

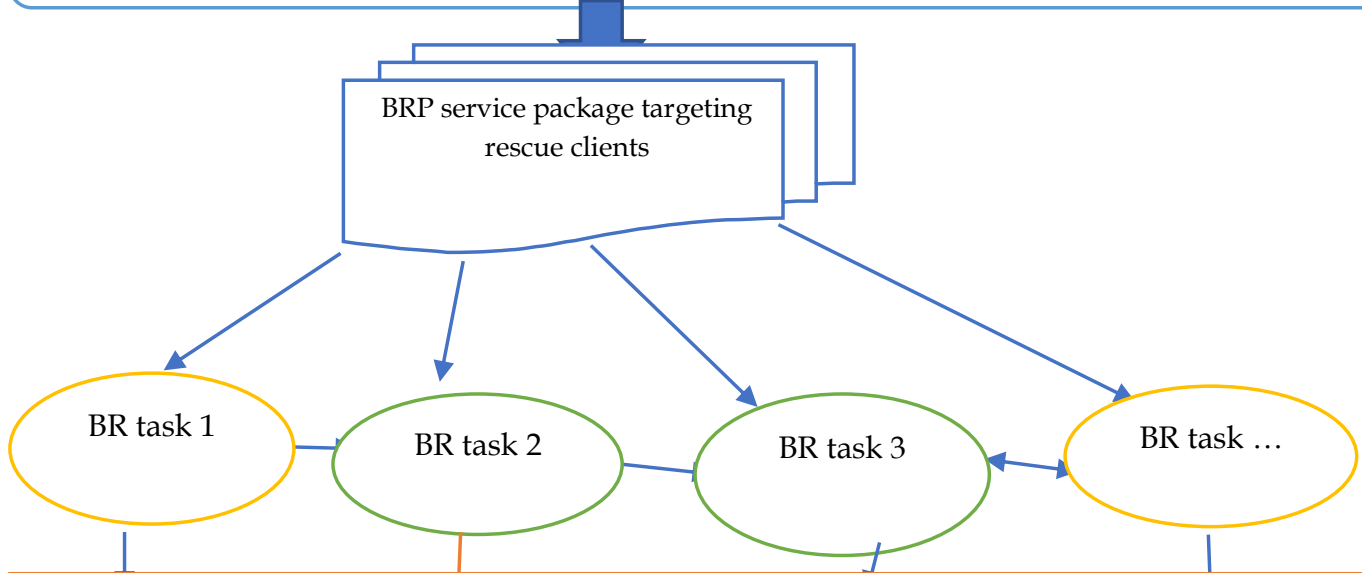

Documentation of task service objectives, methods, process, knowledge, organisation of work, etc [Skills, procedures, processes, productivity, and outputs)

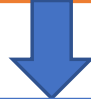

Articulation of the BRP scope of work, expert profile, and professional competences

Learning and development framework [addressing professional behaviour, attitude, and intellect]

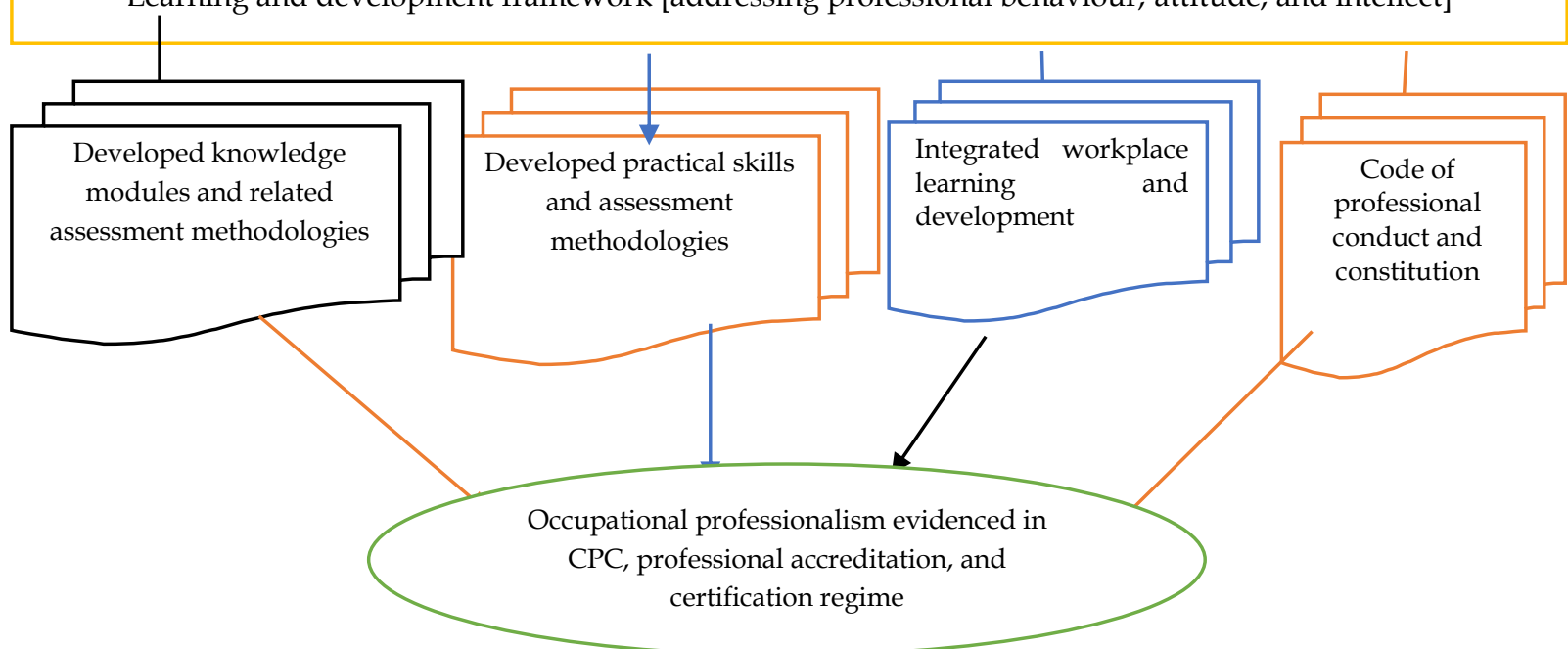

Source: Constructed from researchers' synthesis of interview results, content analysis of legal prescripts, content analysis of scholarly literature. 


\section{Implications}

The multidimensional aspects of professionalism led us to explore a pragmatic approach to construct, investigate, and document professionalism in the BRP occupation (Figure 1). Our examination revealed that a practitioner dealing with the client (given services required), the $\mathrm{PB}$, the public and others, and oneself contribute to a practitioner's essence of being in the work context. The defined dealings are relevant in the delineation of the BRP as a discipline worth professional and academic pursuit. We conclude that professionalism is a multidimensional construct and relational within the MPB occupation setting. The multidimensional aspects are in designing a professional accreditation framework to create a uniform basis of practitioner learning and development.

The different PBs are not bound up with similar socially constructed notions of professionalism. Some of the PBs have a history of providing business consultancy services alongside other services. These PBs have notions of professionalism that reflect the business rescue profession as an additional service that add to their members' already embraced notions. Moreover, the social construction of professionalism is linked to the practitioner's essence of being at the workplace, which starts with higher education training. Therefore, the notions of dealings with clients, government, and others, PBs, and oneself in the context of the business rescue profession cannot be divorced from the past. Models of BRPs' tasks and services are based on the legislated requirements, and practitioners' explanations of practices, ethics and values are key to the refinement of the BRP occupation. The findings of the study point to the need for a pragmatic framework to help construct, understand, document, and investigate what constitutes professionalism in the BRP occupation. Theories on professionalism and professional competence emphasise specialist knowledge, skills, and work performance to the exclusion of a practitioner's essence of being in the work context.

\section{Limitations of the study and directions for future research}

Currently licensed BRPs were not interviewed. The conclusions were derived from interviews with the $\mathrm{PBs}^{\prime}$ representatives and content analysis of CPCs and scholarly literature. Therefore, detailed interviews for double and purposive interpretation are needed to provide a grounded basis to construct, understand and investigate professionalism as an organising framework for practitioners drawn from MPBs. Purposive interpretation is pertinent to future research because the BRP occupation is a regulated practice. The understanding of BRP practices requires purposive interpretation of the legal prescripts on the BR process.

Practitioners in communities of practice have not been used to suggest how professionalism can be enacted comprehensively through experience. Furthermore, investigations are needed to establish professional trajectories regarding occupational practice specifics, including business rescue strategies and turnaround risks. Another aspect worth investigating is how PBs vary in practising business rescue management and how this reflects the more comprehensive international practices. An additional issue is to investigate the degree to which professionalism is the fundamental vehicle for enhancing professional practices in emerging fields. Such investigations may require a historical exposition of a practitioner's essence of being through different stages of an occupation's evolution.

\section{References}

Arnold, L. (2002). Assessing professional behavior: yesterday, today, and tomorrow. Academic medicine, 77(6), pp. 502-515.

Askary, S. (2006). Accounting professionalism-a cultural perspective of developing countries. Managerial auditing journal, 21(1/2), pp. 102-111.

Barbosa, M. W., Freitas, J. S., \& Ladeira, M. B. (2017). Qualitative studies in supply chain management research: potential contributions of centring resonance analysis. International Journal of Logistics Systems and Management, 28(1), pp. 42-58

Bartels, J., Pruyn, A., De Jong, M. and Joustra, I. (2007). Multiple organisational identification levels and the impact of perceived external prestige and communication climate. Journal of Organizational Behavior: The International Journal of Industrial, Occupational and Organisational Psychology and Behavior, 28(2), pp. 173-190. 
Bell, B. and Cowie, B. (2001). The characteristics of formative assessment in science education. Science education, 85(5), pp. 536-553.

Canary, H. E., and Jennings, M. M. (2008). Principles and influence in codes of ethics: A centering resonance analysis comparing pre-and post-Sarbanes-Oxley codes of ethics. Journal of Business Ethics, 80(2), pp. 263-278.

CIPC (2013). Do all answers rest in the skill set of the business rescue practitioner? Pretoria: Unpublished presentation.

CIPC (2020). Business rescue continuing professional development policy. Government Gazetter No. 882, pp. 24-32.

Corman, S.R., Kuhn, T., McPhee, R.D. and Dooley, K.J. (2002) 'Studying complex discursive systemscentering resonance analysis of communication', Human Communication Research, Vol. 28, No. 2, pp.157-206

Deverell, E. (2021). sProfessionalisation of crisis management: A case study of local-level crisis communicators in Sweden. Journal of Contingencies and Crisis Management, 29(2), 131-142.

Dooley, K. J. (2016). Using manifest content analysis in purchasing and supply management research. Journal of Purchasing and Supply Management, 22(4), pp. 244-246.

Evans, L. (2011). The 'shape' of teacher professionalism in England: Professional standards, performance management, professional development and the changes proposed in the 2010 White Paper. British educational research journal, 37(5), 851-870.

Evetts, J. (2000). The European professional federations: occupational regulation in European markets. Discussion paper Centre for Professions and Professional Work, School of Sociology and Social Policy. University of Nottingham, UK.

Evetts, J. (2003) The sociological analysis of professionalism: occupational change in the modern world. International Sociology, 18(2), 395-415.

Fatemi, D., Hasseldine, J., and Hite, P. (2020). The influence of ethical codes of conduct on professionalism in tax practice. Journal of Business Ethics, 164(1), 133-149.

Freidson, E. (2001). Professionalism: the third logic, London: Polity Press

Gaumnitz, B. R. and J. C. Lere (2002). Contents of Codes of Ethics of Professional Organizations in the United States, Journal of Business Ethics, 35(1), pp. 35-50

Gaumnitz, B. R. and J. C. Lere (2004). A Classification Scheme for Codes of Business Ethics, Journal of Business Ethics, 49(4), pp. 329-335.

Henderson, D., Jackson, V., Simmons, S., and Edwards, D. W. (2012). Preparation for Successful Clinical Experiences: A Collaborative Perspective on Internship Orientation. Journal of Best Practices in Health Professions Diversity: Education, Research \& Policy, 5(1), pp. 774-789

Henning, M. A., Ram, S., Malpas, P., Sisley, R., Thompson, A., and Hawken, S. J. (2014). Reasons for academic honesty and dishonesty with solutions: a study of pharmacy and medical students in New Zealand. Journal of medical ethics, 40(10), pp. 702-709.

Howard, G. R. (2007). Dispositions for good teaching. Journal of Educational Controversy, 2(2), pp. 191-198.

Hwang, H., \& Colyvas, J. A. (2011). Problematising actors and institutions in institutional work. Journal of Management Inquiry, 20(1), pp. 62-66.

Kolb, S. M. (2012). Grounded theory and the constant comparative method: Valid research strategies for educators. Journal of emerging trends in educational research and policy studies, 3(1), pp. 83-86.

Kolsaker, A. (2008) Academic professionalism in the managerialist era: a study of English universities, Studies in Higher Education, 33(5), pp. 513.

Lail, B., MacGregor, J., Marcum, J., and Stuebs, M. (2017). Virtuous professionalism in accountants to avoid fraud and to restore financial reporting. Journal of business ethics, 140(4), pp. 687-704.

Macheridis, N. and Paulsson, A., 2019. Professionalism between profession and governance: how university teachers' professionalism shapes coordination. Studies in Higher Education, 44(3), pp.470485.

Montazemi, A. R., Siam, J. J., and Esfahanipour, A. (2008). Effect of network relations on the adoption of electronic trading systems. Journal of Management Information Systems, 25(1), pp. 233-266.

Muzio, D., Brock, D. M., and Suddaby, R. (2013). Professions and institutional change: Towards an institutionalist sociology of the professions. Journal of management studies, 50(5), pp. 699-721. 
Pareto, V. (2017). The rise of professionalism: Monopolies of competence and sheltered markets. Routledge.

Pretorius, M. (2014). A competency framework for the business rescue practitioner profession. Professional Accountant, 14(2), pp. 1-15.

Rajaram, R., and Singh, A. M. (2018). Competencies for the effective management of legislated business rehabilitations. South African Journal of Economic and Management Sciences, 21(1), pp. 1-9.

Sandberg, J., and Pinnington, A. H. (2009). Professional competence as ways of being: An existential ontological perspective. Journal of management studies, 46(7), 1138-1170.

Shafer, W. E. (2002). Ethical pressure, organisational-professional conflict, and related work outcomes among management accountants. Journal of Business Ethics, 38(3), pp. 261-273.

Van De Camp, K., Vernooij-Dassen, M. J., Grol, R. P., \& Bottema, B. J. (2004). How to conceptualise professionalism: a qualitative study. Medical teacher, 26(8), pp. 696-702.

Van Mook, W. N., van Luijk, S. J., O'Sullivan, H., Wass, V., Zwaveling, J. H., Schuwirth, L. W., and van der Vleuten, C. P. (2009). The concepts of professionalism and professional behaviour: conflicts in both definition and learning outcomes. European Journal of Internal Medicine, 20(4), pp. e85-e89.

Wagner, P. A. (2012). Legal ethics no paradigm for educational administrators. Journal of Thought, 47(1), pp. 21-37.

Wahyuni, D. (2012). The research design maze: Understanding paradigms, cases, methods, and methodologies. Journal of applied management accounting research, 10(1), pp. 69-80.

Wright, R. (2008). Sexual harassment and professional ethics. The SAA Archaeological Record, 8(4), 27-30.

Yin, R. K. (2018). Case study research and applications: Design and methods (6 $6^{\text {th }} \mathrm{Ed}$ ). London: Sage publications Limited.

Yiu, C. (2008). A new model to help students develop professional ethics. Journal of Real Estate Practice and Education, 11(1), pp. 41-56. 